Article

\title{
Findings from Community-Based Screenings for Type 2 Diabetes Mellitus in at Risk Communities in Cape Town, South Africa: A Pilot Study
}

\author{
Jillian Hill ${ }^{1} * \mathbb{(}$, Nasheeta Peer ${ }^{1}$, Deborah Jonathan ${ }^{1}$, Mary Mayige ${ }^{2}{ }^{\oplus}$, Eugene Sobngwi ${ }^{3}$ and \\ Andre Pascal Kengne ${ }^{1}$ (D) \\ 1 Non-Communicable Diseases Research Unit, South African Medical Research Council (SAMRC), \\ Cape Town 7505, South Africa; nasheeta.peer@mrc.ac.za (N.P.); Deborah.Jonathan@mrc.ac.za (D.J.); \\ andre.kengne@mrc.ac.za (A.P.K.) \\ 2 National Institute for Medical Research, Dar es Salaam 11000, Tanzania; maryma13@yahoo.com \\ 3 Department of Medicine, University of Yaounde, Yaounde 00000, Cameroon; sobngwieugene@yahoo.fr \\ * Correspondence: jillian.hill@mrc.ac.za
}

Received: 26 March 2020; Accepted: 13 April 2020; Published: 21 April 2020

check for updates

\begin{abstract}
Completed and ongoing implementation activities globally advocate for community-based approaches to improve strategies for type 2 diabetes prevention. However, little is known about such strategies in the African region where there are higher relative increases in diabetes prevalence. We reported findings from the first 8-month pilot phase of the South African diabetes prevention program. The study was conducted across eight townships (four black and four mixed-ancestry communities) in Cape Town, South Africa, between August 2017 and March 2018. Participants were recruited using both random and self-selected sampling techniques because the former approach proved to be ineffective; $<10 \%$ of randomly selected individuals consented to participate. Non-laboratory-based diabetes risk screening, using the African diabetes risk score, and based on targeted population specific cut-offs, identified potentially high-risk adults in the community. This was followed by an oral glucose tolerance test (OGTT) to confirm prevalent pre-diabetes. Among the 853 adults without prior diabetes who were screened in the community, 354 (43.4\%) were classified as high risk, and 316 presented for further screening. On OGTT, $13.1 \%$ had dysglycemia, including $10 \%$ with screen-detected diabetes and $67.9 \%$ with glycated haemoglobin (HbA1c)-defined high risk. Participants with pre-diabetes $(n=208)$ had high levels of common cardiovascular risk factors, i.e., obesity (73.7\%), elevated total cholesterol $(51.9 \%)$, and hypertension (29.4\%). Self-referral is likely an efficient method for selecting participants for community-based diabetes risk screening in Africa. Post-screening management of individuals with pre-diabetes must include attention to co-morbid cardiovascular risk factors.
\end{abstract}

Keywords: diabetes risk; community screening; cardiovascular disease; hypertension; dyslipidemia

\section{Background}

Increasingly, community-based risk screening actions are advocated to reduce the growing global burden of type 2 diabetes mellitus (T2DM). The burden of T2DM in sub-Saharan Africa (SSA) is substantial and growing rapidly. The population of people with diabetes in SSA is expected to increase by $142.9 \%$ from 19.4 million in 2019 to 47.1 million people in 2045 [1]. Of the countries in SSA, South Africa already has the second largest number of people with diabetes. In 2017, there were 1,826,100 cases of diabetes recorded in adults [2], with the greatest burden experienced by socio-economically disadvantaged populations. Recent prevalence rates in these populations, i.e., $13.1 \%$ in blacks [3] and $26.3 \%$ in mixed ancestry [4], are similar to those in populations known to be 
at high-risk for T2DM. While appropriate management of people already diagnosed with T2DM is essential, identifying those at high-risk and preventing or postponing the progression to T2DM is equally important.

Although there is definitive evidence on the effectiveness of lifestyle interventions in preventing diabetes among high-risk individuals [5,6], little is known about implementing these interventions in real-life settings in SSA. The South African diabetes prevention program (SA-DPP) aims to develop and evaluate a culturally relevant T2DM prevention model for South Africa, using evidence from successful diabetes prevention effectiveness and implementation programs [7-10]. The goal is to arrive at a model that will inform lifestyle interventions to prevent T2DM and other lifestyle-related conditions at primary health care level in South Africa. This may serve as a model for adaptation in other SSA countries that are confronted with similar challenges as South Africa. The first phase of this study was the recruitment and screening process. In this manuscript, we reported on the findings of the screening activities of the SA-DPP pilot study.

\section{Materials and Methods}

\subsection{Study Design and Population}

The target population included black and mixed-ancestry participants between the ages of 25 and 65 , without known diabetes. The SA-DPP sample size was calculated, assuming a cumulative incident diabetes rate of $13.6 \%$ at $2-3$ years, as observed in our Bellville South cohort [11], with an expected relative risk to be 0.51 , which is the pooled effect estimate of efficacy trials comparing lifestyle intervention vs. usual care in preventing [12]. We further assumed an intra-cluster correlation coefficient (ICC) for fasting glucose of 0.02 [13]. The sample size calculation was based on the above at a significance level of 5\% with a type II error risk of $20 \%$ and with an estimated 36 months loss to follow-up of $20-25 \%$. Recruiting 56 clusters of 20 participants would provide adequate power for detecting a significant effect on incident T2DM after three years of follow-up in those with pre-diabetes. Importantly, the study would be able to demonstrate significant changes in intermediate outcomes (weight and body mass index (BMI)) after the first year of the intervention. This, in turn, would inform the scalability of the project ahead of completion.

The pilot sample of the SA-DPP comprised eight low-socioeconomic townships in Cape Town, South Africa, with four groups each from the black and mixed-ancestry communities (Table 2). This would enable equal distribution of the intervention and control arms by population groups. The pilot study thus consisted of 160 participants (eight groups $\times 20$ participants), which was about $14 \%$ of the total sample required for the intervention phase. To identify 160 individuals at high-risk for T2DM, it was estimated that 910 individuals would need to be invited to undergo screening. With an estimated response rate of $80 \%$, it was expected that 728 individuals would avail themselves for home screening. Of these, 364 would require oral glucose tolerance tests (OGTTs), and 160 were expected to be identified as high-risk. 
Table 1. Area demographics of included communities.

\begin{tabular}{|c|c|c|c|c|c|}
\hline Area & Total Population & Level of Education & Average Income & Number of Schools & Number of Health Facilities \\
\hline $\begin{array}{c}\text { Khayelitsha SP } \\
\text { (informal settlement) } \\
\text { Predominantly black community }\end{array}$ & $11,251\left(2357.23 / \mathrm{km}^{2}\right)$ & No info & No info & No info & No info \\
\hline $\begin{array}{c}\text { Belhar } \\
\text { (Ward } 12 \text { and 22) } \\
\text { Predominantly mixed-ancestry } \\
\text { community }\end{array}$ & $56,234\left(6882.25 / \mathrm{km}^{2}\right)$ & $\begin{array}{l}\text { No schooling aged } 20+(1.4 \%) \text {. } \\
\text { Higher education aged } 20+(9.4 \%) \text {. } \\
\text { Matric aged } 20+(29 \%) .\end{array}$ & $\begin{array}{c}\text { Average household income: } \\
\text { No income }=8.3 \% . \\
\text { R1-R4800 }=1 \% . \\
\text { R4801-9600 }=1.8 \% \\
\text { R9601-R19,600 }=8.9 \% \\
\text { R19,601-38,200 }=14.9 \% . \\
\text { R38,201-76,400 }=20.2 \% . \\
\text { R76,401-R153,800 }=20.8 \% \\
\text { R153,801-R307,600 }=15.3 \% . \\
\text { R307, } 601-\mathrm{R} 614,400=6.9 \% \\
\text { R614,401-R1,228,800 }=1.4 \% .\end{array}$ & \pm 20 & 2 (St Vincent clinic and Chestnut CHC) \\
\hline $\begin{array}{c}\text { Athlone } \\
\text { (Ward 49) } \\
\text { Predominantly mixed-ancestry } \\
\text { community }\end{array}$ & $8893\left(5900 / \mathrm{km}^{2}\right)$ & $\begin{array}{l}71.9 \% \text { completed grade } 9 \text { or higher. } \\
35.6 \% \text { completed matric or higher. }\end{array}$ & $\begin{array}{c}\text { Average household income: } \\
\text { No income }=11.5 \% . \\
\text { R1-R4800 }=1.7 \% . \\
\text { R4801-9600 }=3.3 \% . \\
\text { R9601-R19,600 }=15.5 \% . \\
\text { R19,601-38,200 }=18.6 \% . \\
\text { R38,201-76,400 }=18.5 \% . \\
\text { R76,401-R153,800 }=15 \% . \\
\text { R153,801-R307,600 }=9.6 \% . \\
\text { R307,601-R614,400 }=4.7 \% . \\
\text { R614,401-R1,228,800 }=1.2 \% \\
\text {.Average annual income }=\text { R57,500 }\end{array}$ & \pm 20 & $\begin{array}{l}6 \text { (Hood road medical center, Dr. } \\
\text { Abdurahman day hospital, Samwumed, } \\
\text { Fresenius medical care and Athlone kidney } \\
\text { and Dialysis center, Al-nisa maternity home, } \\
\text { and Kromboom dental center) }\end{array}$ \\
\hline $\begin{array}{c}\text { Bongweni } \\
\text { Predominantly black community }\end{array}$ & $1791\left(9420.58\right.$ per $\left.\mathrm{km}^{2}\right)$ & No info & No info & \pm 11 to 15 & $\begin{array}{l}3 \text { (Khayelitsha community health clinic, } \\
\text { Clinimed medical and asthetic solutions, and } \\
\text { mens clinic international) }\end{array}$ \\
\hline $\begin{array}{c}\text { Lavender hill } \\
\text { (Ward 68) } \\
\text { Predominantly mixed-ancestry } \\
\text { community }\end{array}$ & $26,372\left(9335.6 / \mathrm{km}^{2}\right)$ & $\begin{array}{l}62.3 \% \text { completed grade } 9 \text { or higher. } \\
26.7 \% \text { completed matric or higher. }\end{array}$ & Average annual income $=$ R57,500 & \pm 7 & $\begin{array}{l}2 \text { (Lavender hill clinic and Sea wind } \\
\text { CHC-TB unit) }\end{array}$ \\
\hline
\end{tabular}


Table 2. Area demographics of included communities.

\begin{tabular}{|c|c|c|c|c|c|}
\hline Area & Total Population & Level of Education & Average Income & Number of Schools & Number of Health Facilities \\
\hline $\begin{array}{l}\text { Gugulethu } \\
\text { (formal and informal housing) } \\
\text { (Ward } 40 \text { and } 41 \text { ) } \\
\text { Predominantly black community }\end{array}$ & $98,468\left(15,161.70 / \mathrm{km}^{2}\right)$ & $\begin{array}{l}78.2 \% \text { completed grade } 9 \text { or higher. } \\
44.2 \% \text { completed matric or higher. }\end{array}$ & $\begin{array}{c}\text { Average household income: } \\
\text { No income }=19.3 \% . \\
\text { R1-R4800 }=5.3 \% . \\
\text { R4801-9600 }=7.1 \% . \\
\text { R9601-R19,600 }=16.5 \% \\
\text { R19,601-38,200 }=23.2 \% \\
\text { R38,201-76,400 }=15.4 \% \\
\text { R76,401-R153,800 }=8.5 \% \\
\text { R153,801-R307,600 }=3.4 \% \\
\text { R307,601-R614,400 }=1.1 \%\end{array}$ & \pm 20 & $\begin{array}{c}2 \text { (Gugulethu medical center and KTC } \\
\text { Gugulethu CHC) }\end{array}$ \\
\hline $\begin{array}{c}\text { DuNoon } \\
\text { (formal and informal housing) } \\
\text { (ward 104) } \\
\text { Predominantly black community }\end{array}$ & $29,268\left(29,518.5 / \mathrm{km}^{2}\right)$ & $\begin{array}{l}70.7 \% \text { completed grade } 9 \text { or higher. } \\
27 \% \text { completed matric or higher. }\end{array}$ & $\begin{array}{l}\text { Average monthly income }=\mathrm{R} 2400 \\
\text { Average annual income }=\mathrm{R} 30,000\end{array}$ & 5 & 1 (DuNoon CHC) \\
\hline $\begin{array}{c}\text { Lotus river } \\
\text { (ward 65) } \\
\text { Predominantly mixed-ancestry } \\
\text { community }\end{array}$ & $38,143\left(7615.72 / \mathrm{km}^{2}\right)$ & $\begin{array}{l}74.8 \% \text { completed grade } 9 \text { or higher. } \\
40.9 \% \text { completed matric or higher. }\end{array}$ & Average annual income $=\mathrm{R} 57,500$ & $\pm 10-15$ & $\begin{array}{c}2 \text { (Lotus river community health clinic and } \\
\text { lotus river public clinic) }\end{array}$ \\
\hline
\end{tabular}




\subsection{Participants Selection}

The details of the included eight townships (four black and four mixed ancestry) are included in Table 2. Participants were initially selected using a random sampling technique. However, this did not prove successful, and the self-selection approach was adopted for pragmatic reasons. In the random selection approach, aerial maps of the included townships (obtained from the municipality of Cape Town) were used to randomly select households. GPS coordinates were randomly selected, and address lists were generated. Fieldworkers then visited these households to identify and screen potentially eligible participants. Participants were eligible for participation if they were between the ages of 25-65 years, without known diabetes. People were excluded if they were bedridden, pregnant, or breastfeeding, or were in receipt of cancer or tuberculosis treatment within the past three months. Households were visited at least three times before generating new lists. This method proved to be unsuccessful in the first four areas, with less than a 10\% response rate. Reasons included people not being at home or simply not wanting to open the door to strangers (with safety being a real issue in these communities), or not being eligible to participate, i.e., not fulfilling the inclusion criteria. In the self-selection approach, the study was advertised through local councilors' offices, churches, schools, as well as flyers, being distributed door-to-door (or dropped in post-boxes) in the community. Potentially interested participants could then come to pre-determined venues in their community for community-based risk screening.

\subsection{Diabetes Risk Screening}

Diabetes risk screening followed a two-stage approach: a community-based risk screening using a risk questionnaire, followed by a clinic-based risk status assessment using biochemical analyses.

\subsection{Community-Based Diabetes Risk Screening}

The development and use of diabetes risk scores based on self-reported or clinical data for both the detection of T2DM and the identification of individuals at high-risk for future T2DM have become evident in recent years. However, the application to low- and middle- income countries, such as those in SSA, remain unclear [18]. Mayige (2014) [19] derived and validated a simple risk score for undiagnosed T2DM in African populations. Age, hypertension, and waist circumference were included in the final model of the African diabetes risk score (ADRS) [19]. The SA-DPP made use of ADRS for community-based T2DM risk screening. Local data and receiver-operating characteristics (ROC) analyses were used to optimize ADRS thresholds for black [3] and mixed-ancestry [4] South Africans, which were 1.46 and $1.15 \%$, respectively (Figure 1 ).

Trained fieldworkers conducted community-based risk screening by administering the brief screening questionnaire (age, gender, and ethnicity) and measuring anthropometry and blood pressure (BP). Three BP measurements were taken at two-minute intervals using an Omron BP monitor after the participant had been seated for five minutes. Height, weight, and waist measurements were measured using standardized techniques [20]. This was used to estimate the risk of T2DM by the ADRS (see parameters in Table 3). Participants deemed at high-risk were referred to our research clinic for biochemical investigations. Participants with blood pressure levels considered to constitute an immediate risk for their health (systolic blood pressure (SBP) $\geq 140$ and or diastolic blood pressure $(\mathrm{DBP}) \geq 90 \mathrm{mmHg}$ ) were referred to a nearby public health facility for further management. 
Table 3. The African diabetes risk score, in those without prior diabetes. SADPP, South African diabetes prevention program.

\begin{tabular}{cc}
\hline \multicolumn{2}{c}{ SADPP Risk Score Calculation } \\
\hline Regression coefficients of the model \\
\hline Variable & Coefficient \\
\hline Age (per 1-year increase) & 0.045 \\
Waist Circumference (per cm increase) & 0.048 \\
Hypertension (present (1) vs. absent (0)) & 0.649 \\
Intercept & -11.012 \\
\hline
\end{tabular}

Diabetes score $=100 \times(1 \div(1+\exp (-(-(11.012)+0.045 \times \mathrm{A}+0.048 \times((\mathrm{B}+\mathrm{C}) \div 2)+0.649 \times(\mathrm{D})))))$. Where A-Age, B-Waist circumference 1 in cm, C-Waist circumference 2 in $\mathrm{cm}$, D-Hypertension: Yes, if Systolic $=140$ or more or Diastolic $=90$ or more or if self-reported history of doctor diagnosed hypertension. Participants with a score $>1.46$ (Black) or $>1.15$ (mixed ancestry).

\subsection{Clinic-Based Diabetes Risk Confirmation and Baseline Measurements}

Participants deemed at high-risk during community-based screening were transported on pre-determined dates to our research clinic for further assessment by our dedicated research drivers. Baseline assessments included OGTTs and other biochemical and clinical assessments. Blood samples for glucose and lipids were drawn after a 10-hour overnight fast, then a standard OGTT using $75 \mathrm{~g}$ of anhydrous glucose in $250 \mathrm{~mL}$ of water was administered, and blood samples were taken $120 \mathrm{~min}$ later [21]. A qualified nurse collected the blood samples.

The trained fieldworkers with $\geq 1$ year of experience administered the questionnaire and performed the anthropometric and BP assessments. Among the data collected were the following: socio-demographic information, personal and family medical history, dietary data using a single non-quantified 24-hour recall, physical activity (global physical activity questionnaire (GPAQ)) [22], and physical environment (neighborhood environment walkability scale (NEWS) Africa) [23] (Table 4). Anthropometric and BP measurements were repeated using the standardized techniques described above.

Table 4. Measurement domains, tools, and data collection for the South African Diabetes Prevention Programme (SADPP) pilot phase.

\begin{tabular}{|c|c|c|c|}
\hline Variable & Components & Measurements Tools/Questions & Reporting in this Paper \\
\hline General information & & Personal details and contacts for follow up & Not reported \\
\hline $\begin{array}{l}\text { Socio-demographic } \\
\text { measures }\end{array}$ & & $\begin{array}{l}\text { Age, gender, area, community, current marital } \\
\text { status, education level, employment, income }\end{array}$ & Reported \\
\hline \multirow{4}{*}{$\begin{array}{l}\text { Self-reported medical } \\
\text { history }\end{array}$} & General & & Not reported \\
\hline & Chronic diseases & $\begin{array}{l}\text { Diabetes, hypertension, cholesterol, } \\
\text { bronchitis/chronic obstructive pulmonary } \\
\text { disease, cancer, tuberculosis }\end{array}$ & Not reported \\
\hline & medication & Chronic prescription medication & Not reported \\
\hline & Family medical history & $\begin{array}{l}\text { Hypertension, diabetes, heart attack, } \\
\text { stroke, cancer }\end{array}$ & $\begin{array}{l}\text { Only familial diabetes } \\
\text { history reported }\end{array}$ \\
\hline \multirow{3}{*}{ Behavioral measures } & Tobacco use & WHO STEPS questionnaire [22] & Reported \\
\hline & Alcohol use & WHO STEPS questionnaire [22] & Reported \\
\hline & Sedentary behavior & Time spent in front of a screen & Reported elsewhere [25] \\
\hline
\end{tabular}


Table 4. Cont.

\begin{tabular}{|c|c|c|c|}
\hline Variable & Components & Measurements Tools/Questions & Reporting in this Paper \\
\hline \multirow{3}{*}{$\begin{array}{l}\text { Physical activity } \\
\text { measures }\end{array}$} & Physical activity pattern & $\begin{array}{l}\text { WHO STEPS questionnaire: global physical } \\
\text { activity questionnaire (GPAQ) [22] }\end{array}$ & Reported elsewhere [25] \\
\hline & Barriers to physical activity & $\begin{array}{l}\text { Scale adapted from the one designed by } \\
\text { Booth et al. [22] }\end{array}$ & Reported elsewhere [25] \\
\hline & Self-efficacy & $\begin{array}{l}\text { Scale adapted from the exercise self-efficacy scale } \\
\text { (ESES) designed by Schwarzer and Jerusalem [28] }\end{array}$ & Reported elsewhere [25] \\
\hline \multirow[b]{3}{*}{ Clinical measures } & Waist circumference & $\begin{array}{l}\text { Measured between the lower border of the } \\
\text { lowest rib and upper border of the iliac } \\
\text { crest/pelvic bone to the nearest } 0.1 \mathrm{~cm}\end{array}$ & Reported \\
\hline & Weight & $\begin{array}{c}\text { Weight measurement with minimal clothing on a } \\
\text { digital (SECA) scale, recorded to the nearest } \\
0.1 \mathrm{~kg}\end{array}$ & Reported (BMI) \\
\hline & Height & $\begin{array}{c}\text { Standing height, minimal clothing, aligning head } \\
\text { in a standard anatomical position using a SECA } \\
\text { stadiometer }\end{array}$ & \\
\hline $\begin{array}{l}\text { Neighborhood } \\
\text { indicators }\end{array}$ & $\begin{array}{l}\text { Stores and facilities, access to } \\
\text { services and places, roads and } \\
\text { walking paths, places for } \\
\text { walking/cycling/playing, } \\
\text { surroundings, safety from } \\
\text { crime and traffic, personal } \\
\text { safety, stranger danger }\end{array}$ & $\begin{array}{l}\text { Neighborhood environment walkability scale } \\
\text { (NEWS) Africa Questionnaire [23] }\end{array}$ & Reported elsewhere [25] \\
\hline \multirow[b]{2}{*}{ Psychological measures } & Chronic stress & Chronic stress scale [29] & Reported elsewhere [25] \\
\hline & $\begin{array}{l}\text { Mood (depression } \\
\text { and anxiety) }\end{array}$ & $\begin{array}{c}\text { Patient health questionnaire-9 amended in line } \\
\text { with CURES-65 study [30], general anxiety } \\
\text { disorder scale [31] }\end{array}$ & Not reported \\
\hline
\end{tabular}

\subsection{Data Entering and Management}

The study used a web-based research system for data collection and management. The project was housed within a research unit that has established experience in data collection using electronic devices. The use of this approach allowed for quality control to be implemented as data was being collected, which, in turn, improved the accuracy of the information collected. Data collected from the field were automatically transferred via a secured internet connection to the central database, which was maintained on an on-going basis. Biological samples were collected and stored in bar-coded containers, which facilitated the incorporation of laboratory results onto the main database.

\subsection{Statistical Analysis}

The required data were downloaded from the electronic database. A database was then created and cleaned in Excel. While in Microsoft Excel 2010 (Excel 365 for Windows, Redmond, Washington D.C., USA), some data (responses) were recoded and/or collapsed for more meaningful analysis. Data coherence, validity, reliability, and exploitability were checked. Descriptive data analysis was done using IBM SPSS Statistics version 25 (IBM, Armonk, New York, NY, USA). At the first level of analysis, univariate analysis or frequencies were run on all variables in the questionnaires. For descriptive purposes, frequencies were tallied, and percentages were calculated. At the second level of analysis, cross-tabulations were conducted to establish differences between groups. Pearson-product moment correlation coefficients were used to measure the strength of linear associations between two variables. Results were expressed in means and standard deviations for continuous variables and counts and percentages for categorical variables. 


\subsection{Bio-Analysis}

Biochemical analyses were conducted in PathCare laboratories. Plasma glucose levels were measured by enzymatic hexokinase method (Beckman AU, Beckman Coulter, Cape Town, South Africa). Glycated haemoglobin (HbA1c) was analyzed with high-performance liquid chromatography (Biorad Variant Turbo, BioRad, Johannesburg, South Africa).

Ethical clearance was obtained from the ethics committee of the South African medical research council (SAMRC) (approval no. EC018-7/2015).

\section{Results}

\subsection{Community Screening}

The random sampling technique proved to be ineffective, with less than $10 \%$ of those selected through this approach consenting to be considered for the study. The self-selection process yielded a more positive response. A thousand and one (1001) adults were screened in eight areas (four black and four mixed-ancestry townships) during this pilot study, of which 158 individuals (59.5\% mixed-ancestry, $76 \%$ female, mean age $=59.7$ years $(11.4 \mathrm{SD})$ ) had already been diagnosed with T2DM (Figure 1).

Of the remaining, $n=843$ (53\% black, 77\% female, mean age 47.3 (10.6 SD)), screened for T2DM and prediabetes, $74 \%$ had a BMI $\geq 25 \mathrm{~kg} / \mathrm{m}^{2}, 24 \%$ had hypertension (BP $\geq 140 / 90 \mathrm{mmHg}$ or known hypertension), and $43.4 \%(n=354)$ were identified as at high risk of T2DM and prediabetes (Table 5). Three hundred and sixteen (89.3\%) at-risk individuals presented themselves at the clinic for further investigation $(81 \%$ female, 55\% black, mean age $=51.8$ years (9 SD)) (Figure 1$)$.

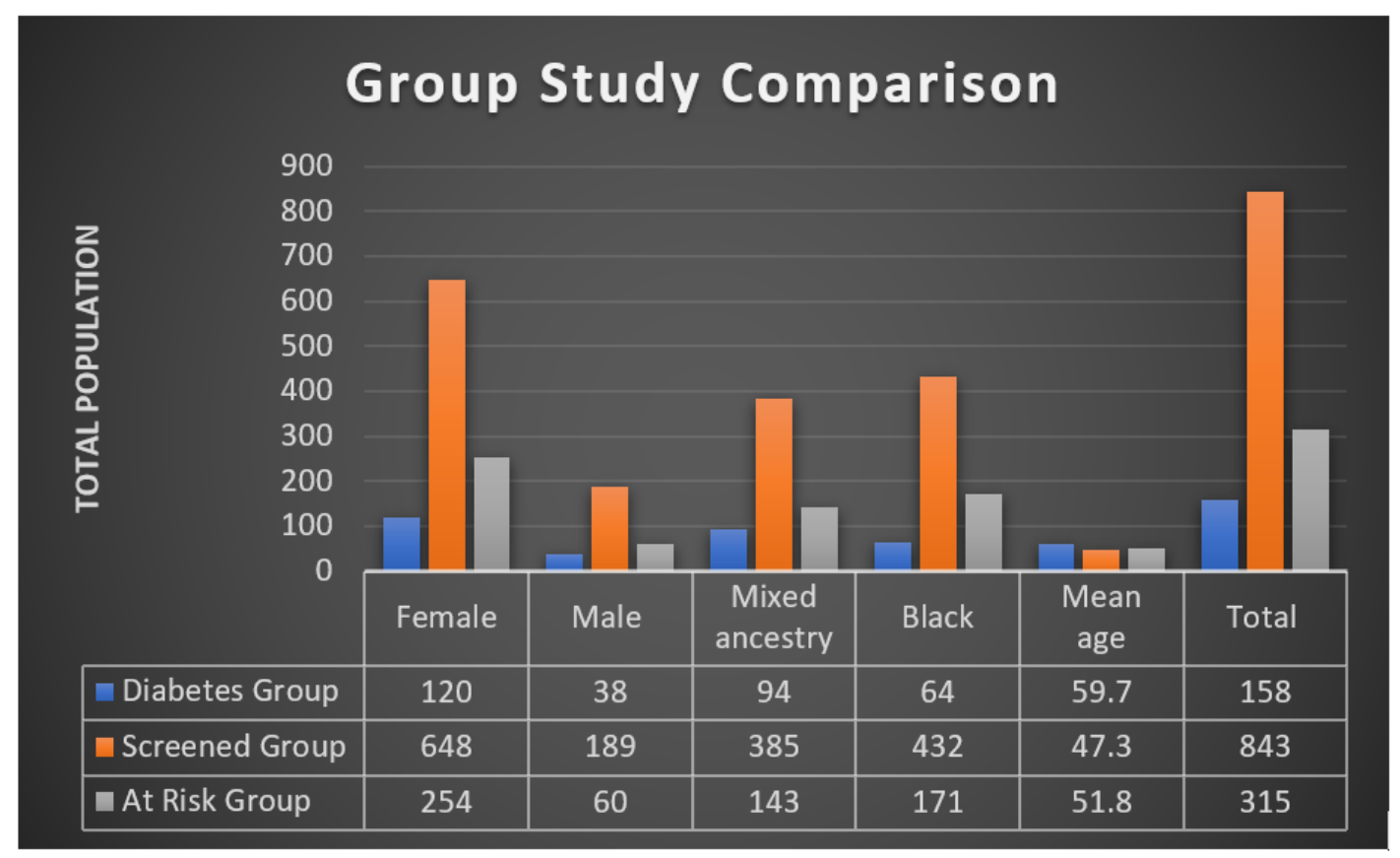

Figure 1. Community-based screening group comparison. 
Table 5. Characteristics of community screened participants.

\begin{tabular}{|c|c|c|c|}
\hline \multicolumn{2}{|c|}{ Characteristic } & \multirow{3}{*}{$\begin{array}{c}N \\
432 \\
385\end{array}$} & \multirow{3}{*}{$\begin{array}{c}\mathbf{\%} \\
52.9 \\
47.1\end{array}$} \\
\hline \multirow{2}{*}{ Ethnicity } & Black & & \\
\hline & Mixed ancestry & & \\
\hline \multirow{2}{*}{ Sex } & Males & 189 & 23 \\
\hline & Females & 648 & 77 \\
\hline Mean age (years) & \multicolumn{2}{|c|}{47.3 (10.6 SD) } & \\
\hline Older than 45 & Yes & 512 & 61.2 \\
\hline \multirow{8}{*}{ Township } & Athlone ${ }^{* *}$ & 85 & 10.4 \\
\hline & Belhar ** & 145 & 17.4 \\
\hline & Bongweni/Tembani * & 19 & 2.4 \\
\hline & Du Noon * & 49 & 5.7 \\
\hline & Gugulethu* & 239 & 28.3 \\
\hline & Khayelisha SP * & 133 & 15.7 \\
\hline & Knole park/Lotus river ${ }^{* *}$ & 75 & 8.9 \\
\hline & Lavender hill ** & 86 & 10.2 \\
\hline \multirow{4}{*}{ Body mass index } & Underweight & 27 & 3.3 \\
\hline & Normal weight & 181 & 22.3 \\
\hline & Overweight & 208 & 25.6 \\
\hline & Obese & 396 & 48.8 \\
\hline $\begin{array}{l}\text { Mean waist circumference } \\
(\mathrm{cm})\end{array}$ & \multicolumn{2}{|c|}{94 (21.9 SD) } & \\
\hline $\begin{array}{c}\mathrm{BP} \geq 140 / 90 \mathrm{mmHg} \text { or known } \\
\text { hypertension }\end{array}$ & Yes & 198 & 24.2 \\
\hline Family history of diabetes & Yes & 244 & 29.2 \\
\hline At risk for diabetes & Yes & 354 & 43.4 \\
\hline
\end{tabular}

* Black; ${ }^{* *}$ Mixed ancestry.

\subsection{Baseline Evaluation (Clinic Screening)}

\section{Socio-Demography}

In the overall sample $(N=316)$, there was $54.4 \%$ black, $80.1 \%$ female, with a mean age of 51.8 years $(\mathrm{SD}=8.9)$ (Table 6$)$, and $43 \%$ had a high school (grade $8-11$ ), and $27.2 \%$ had grade 12 and higher. Of the study sample, 38.9\% were unemployed, $23.8 \%$ received a grant (pension/disability/child), and the majority $(75.6 \%)$ had a monthly household income of less than R3201 ( \pm 218 \$) (Table 6). There were differences between the population groups of mixed ancestry vs. black participants who were significantly older (mean age: 54 (7.7) vs. 49 (9.5)), less educated (tertiary education: 9\% vs. $22.6 \%$ ), and less unemployed (32.8\% vs. 49.1\%). However, employment levels were comparable between the groups, while a significantly higher proportion of mixed-ancestry participants were fulltime homemakers. Further, mixed-ancestry participants had higher income levels, with $33.7 \%$ of household income above R6401 p/m vs. 13.7\% for black participants. 
Table 6. Socio-demographic characteristics of participants who presented for clinic screening.

\begin{tabular}{|c|c|c|c|c|}
\hline \multicolumn{5}{|c|}{ Socio-Demographic Characteristics $(N=316)$} \\
\hline & & $\begin{array}{l}\text { General } \\
\text { Population }\end{array}$ & $\begin{array}{l}\text { Black } 177 \\
(54.2 \%)\end{array}$ & $\begin{array}{c}\text { Mixed-Ancestry } \\
141(45.7 \%)\end{array}$ \\
\hline Age, mean (SD) & \multicolumn{2}{|c|}{$51.8(8.9)$} & $49(9.5)$ & $54(7.7)^{* *}$ \\
\hline Gender & $N$ & $\%$ & \multicolumn{2}{|c|}{$N(\%)$} \\
\hline Male & 60 & 19.0 & $30(17.5)$ & $30(20.8)$ \\
\hline Female & 253 & 80.1 & $141(82.5)$ & 114 (79.5) \\
\hline NA & 3 & 0.9 & & \\
\hline \multicolumn{5}{|l|}{ Education } \\
\hline Never went to school & 2 & 0.6 & $1(0.6)$ & $1(0.7)$ \\
\hline Primary school (grades 1-7) & 76 & 24.1 & $36(21.4)$ & $41(28.3)$ \\
\hline High school (grades 8-12) & 136 & 43.0 & 67 (39.9) & $69(47.6) *$ \\
\hline Less than grade $12+\mathrm{FET}^{*} /$ certificate/diploma & 11 & 3.5 & $6(36)$. & $5(3.4)$ \\
\hline Grade 12 & 36 & 11.5 & $20(11.9)$ & $16(11)$ \\
\hline Tertiary/diploma/degree & 51 & 16.3 & 38 (22.6) & $13(9) *$ \\
\hline Not Assigned & 5 & 1.6 & & \\
\hline \multicolumn{5}{|l|}{ Occupation } \\
\hline Employed (full- or part-time/self-employed) & 93 & 29.4 & $53(29.9)$ & $40(28.6)$ \\
\hline Unemployed & 133 & 42 & $87(49.1)$ & $46(32.8)$ \\
\hline Full-time homemaker & 21 & 6.6 & $2(1.1)$ & 19 (13.5) \\
\hline Pensioner & 58 & 18.4 & $21(11.9)$ & $37(26.2)$ \\
\hline On a disability grant & 13 & 4.1 & 5 & 8 \\
\hline Child grant & 4 & 1.3 & 3 & 1 \\
\hline \multicolumn{5}{|l|}{ Income } \\
\hline No income & 32 & 10.2 & $23(13.7)$ & $9(6.2) * *$ \\
\hline R1-R400 & 12 & 3.8 & $12(7.1)$ & 0 \\
\hline R401-R800 & 27 & 8.6 & $18(10.7)$ & $9(8.6)$ \\
\hline R801-R1600 & 75 & 24 & $41(24.4)$ & $34(23.4) * *$ \\
\hline R1601-R3200 & 95 & 30.4 & $51(30.4$ & 44 (30.3) \\
\hline R3201-R6400 & 42 & 13.2 & $16(9.5)$ & $26(17.9) * *$ \\
\hline R6401-R12,800 & 19 & 6.1 & $4(2.4)$ & $15(10.3)^{* *}$ \\
\hline R12,801-R25,600 & 10 & 3.2 & $3(1.8)$ & $7(4.8)^{* *}$ \\
\hline R25,601-R51,200 & 1 & 0.3 & 0 & $1(0.7)$ \\
\hline
\end{tabular}

FET ${ }^{*}-$ Further education and training. ${ }^{*} p$-value $<0.5 ;{ }^{* *} p$-value $\leq 0.001$.

\subsection{Health Risks}

In this high-risk population, mean BMI and waist circumference (WC) were 36 (7.7) and 104 (13.2) (Table 7), respectively, with no significant differences between population groups. Only $3.8 \%$ of the sample had a normal BMI, 21.2\% was overweight, and $73.7 \%$ was obese. The prevalence of hypertension was $30 \%$, HbA1c $>5.7 \%$ was $68 \%$, impaired fasting glucose (IFG) was $5.8 \%$, and impaired glucose tolerance (IGT) was $13.2 \%$. Diabetes was diagnosed in $10 \%$ of the sample. Forty five percent of the population reported having at least one family member with T2DM.

A significant difference was noted between the black and mixed-ancestry populations in the occurrence of elevated $\mathrm{HbA} 1 \mathrm{c}(p<0.05)$.

The prevalence of dyslipidemia was as follows: total cholesterol $\geq 5 \mathrm{mmol} / \mathrm{L}: 48 \%$, high-density lipoprotein cholesterol (HDL-C) < $1.2 \mathrm{mmol} / \mathrm{L}$ : 52.9\%, low-density lipoprotein cholesterol (LDL-C) $\geq 3 \mathrm{mmol} / \mathrm{L}: 57.7 \%$, and triglycerides (TG) $>1.5 \mathrm{mmol} / \mathrm{L}: 35.8 \%$. Mixed-ancestry participants compared with their black counterparts had significantly worse profiles for all lipid parameters.

Regarding alcohol consumption, $13.3 \%$ of participants drank several times per week, while $55.1 \%$ abstained. Over a quarter $(26.3 \%)$ of participants were current smokers. By population group, the prevalence of alcohol abstainers was significantly higher in the mixed ancestry vs. black group (45.3\% vs. $65.8 \%)$. The former population compared with the latter was more likely to be current smokers (20.9\% vs. $49 \%$ ) (Table 7$)$. 
Table 7. Health and behavioral risk factors among participants who presented for clinic screening.

\begin{tabular}{|c|c|c|c|c|}
\hline \multicolumn{5}{|c|}{ Risks Factors $(N=316)$} \\
\hline & Gener & ulation & Black & Mixed-Ancestry \\
\hline Body Mass Index $\left(\mathrm{BMI}, \mathrm{kg} / \mathrm{m}^{2}\right)$, mean (SD) & \multicolumn{2}{|c|}{$36(7.7)$} & $36.9(8.3)$ & $35.1(6.9)$ \\
\hline Waist circumference (cm), mean (SD) & \multicolumn{2}{|c|}{$104(13.2)$} & $103.9(13.9)$ & $104.4(12.5)$ \\
\hline BMI & $\mathrm{N}$ & $\%$ & $N(\%)$ & $N(\%)$ \\
\hline Underweight $(<18.5)$ & $\mathrm{X} 0$ & 0 & 0 & 0 \\
\hline Normal weight (18.5-24.9) & 12 & 3.8 & $(4.1)$ & (3.6) \\
\hline Overweight (25.0 to 29.9$)$ & 67 & 21.2 & (21.6) & (20.1) \\
\hline Obese & 233 & 73.7 & (74.3) & (76.3) \\
\hline Not documented & 4 & 1.3 & & \\
\hline \multicolumn{5}{|l|}{ Family medical history } \\
\hline Having at least one known diabetic close relative & 141 & 44.6 & $70(40.9)$ & $71(49.7)$ \\
\hline Don't have one known diabetic close relative & 57 & 18.0 & 99 (57.9) & $68(47.6)$ \\
\hline Don't know & 114 & 36.1 & $2(1.2)$ & $4(2.8)$ \\
\hline Not documented & 4 & 1.3 & & \\
\hline \multicolumn{5}{|l|}{ Blood pressure } \\
\hline Optimal/normal (<120/120-129 mmHg/<80/80-84 mmHg) & 129 & 40.8 & (35.7) & $(47.5)^{*}$ \\
\hline High normal $(130-139 \mathrm{mmHg} / 85-89 \mathrm{mmHg})$ & 71 & 22.5 & (25.7) & $(19.4) *$ \\
\hline Hypertension $(\geq 140 \mathrm{mmHg} / 90 \mathrm{mmHg})$ & 93 & 29.4 & (33.3) & $(25.9) *$ \\
\hline Isolated systolic hypertension $(\geq 140 \mathrm{mmHg} /<90 \mathrm{mmHg})$ & 19 & 6.0 & (5.3) & $(7.2) *$ \\
\hline Not documented & 4 & 1.3 & & \\
\hline \multicolumn{5}{|l|}{ Glycosylated hemoglobin (HbA1c) } \\
\hline$\geq 5.7 \mathrm{mmol} / \mathrm{L}$ & 208 & 67.9 & $104(62.3)$ & $104(74.3) *$ \\
\hline Not documented & 11 & 3.5 & & \\
\hline \multicolumn{5}{|l|}{ Glycemia } \\
\hline Impaired fasting glucose $(>6.1-7 \mathrm{mmol} / \mathrm{L})$ & 18 & 5.8 & $10(5.9)$ & $8(5.8)$ \\
\hline Impaired glucose tolerance $(\geq 7.8-11.1 \mathrm{mmol} / \mathrm{L})$ & 41 & 13.2 & $22(12.9)$ & $19(13.7)$ \\
\hline Diabetic (IFG $>7 \mathrm{mmol} / \mathrm{L}$ and IGT $>11.1 \mathrm{mmol} / \mathrm{L}$ ) & 31 & 10 & $15(8.8)$ & $16(11.3)$ \\
\hline \multicolumn{5}{|l|}{ Cholesterol } \\
\hline Total cholesterol (>5 mmol/L) & 150 & 48.2 & $68(40)$ & $82(58.2) * *$ \\
\hline HDL cholesterol ( $<1.2 \mathrm{mmol} / \mathrm{L})$ & 166 & 52.9 & $79(47)$ & $85(60.3) *$ \\
\hline LDL cholesterol (>3 mmol/L) & 179 & 57.7 & $78(47.6)$ & $99(70.2) * *$ \\
\hline Triglycerides $(>1.5 \mathrm{mmol} / \mathrm{L})$ & 113 & 35.8 & $47(27.6)$ & $63(44.7)^{* *}$ \\
\hline \multicolumn{5}{|l|}{ Alcohol consumption } \\
\hline Abstainer & 174 & 54.8 & $78(45.3)$ & $98(65.8)^{* *}$ \\
\hline Less than once a month & 51 & 15.9 & $32(18.6)$ & $19(12.8) * *$ \\
\hline $1-3$ days per month & 45 & 14 & $30(17.4)$ & $15(10.1) * *$ \\
\hline Several times per week & 42 & 13.1 & $31(18.0)$ & $11(7.4) * *$ \\
\hline Not documented & 7 & 2.2 & & \\
\hline \multicolumn{5}{|l|}{ Tobacco status } \\
\hline Non-smoker & 191 & 59.95 & $125(72.7)$ & $66(44.3)^{* *}$ \\
\hline Current smoker (daily or occasionally) & 109 & 34 & $36(20.9)$ & $73(49) * *$ \\
\hline Ex-smoker & 14 & 4.4 & $10(5.8)$ & $4(2.7) * *$ \\
\hline Not documented & 7 & 2.2 & & \\
\hline
\end{tabular}

${ }^{*} p$-value $<0.5 ;{ }^{* *} p$-value $\leq 0.001 ; \mathrm{cm}$ —centimeter; IFG—impaired fasting glucose; IGT—impaired glucose tolerance; HDL-high-density lipoprotein; LDL-low-density lipoprotein.

When comparing normoglycemia, dysglycemia (participants with impaired IFG and/or IGT), and diabetic groups, the overall cardiovascular disease (CVD) risk profile did not vary significantly except for $\mathrm{HbA} 1 \mathrm{c}$, with $100 \%$ of the diabetic group having raised $\mathrm{HbA} 1 \mathrm{c}$ levels, compared to $78 \%$ (dysglycemia) and 59.4\% (normoglycemia) (Table 8). 
Table 8. Significant differences in cardiovascular disease (CVD) risk factors and glycemic status.

\begin{tabular}{|c|c|c|c|c|}
\hline \multirow{2}{*}{ Glycemic Status } & Normoglycemia $(n=239)$ & Dysglycemia $(n=41)$ & Diabetic $(n=31)$ & \multirow{2}{*}{$p$-Value } \\
\hline & (IFG $<6$ and IGT $<7.8)$ & $\begin{array}{c}(\mathrm{IFG}>6.1-7 \mathrm{mmol} / \mathrm{L} \text { and } \\
\mathrm{IGT} \geq 7.8-11.1 \mathrm{mmol} / \mathrm{L})\end{array}$ & $\begin{array}{c}(\mathrm{IFG}>7 \mathrm{mmol} / \mathrm{L} \text { and } \\
\mathrm{IGT}>11.1 \mathrm{mmol} / \mathrm{L})\end{array}$ & \\
\hline $\mathrm{HbA} 1 \mathrm{c}(\geq 5.7 \mathrm{mmol} / \mathrm{L})$ & $142(59.4)$ & $32(78)$ & $31(100)$ & $<0.0001$ \\
\hline $\begin{array}{l}\text { Total cholesterol }(>5 \\
\mathrm{mmol} / \mathrm{L})\end{array}$ & $116(48.5)$ & $16(39)$ & $15(46.8)$ & 0.525 \\
\hline $\begin{array}{l}\text { HDL cholesterol }(<1.2 \\
\mathrm{mmol} / \mathrm{L})\end{array}$ & $84(35)$ & $19(46.3)$ & $15(46.8)$ & 0.159 \\
\hline $\begin{array}{l}\text { LDL cholesterol (>3 } \\
\mathrm{mmol} / \mathrm{L})\end{array}$ & $122(51)$ & $19(46.3)$ & $19(59.4)$ & 0.544 \\
\hline $\begin{array}{c}\text { Triglycerides }(>1.5 \\
\mathrm{mmol} / \mathrm{L})\end{array}$ & $77(32.2)$ & $16(39)$ & $15(46.8)$ & 0.169 \\
\hline $\begin{array}{l}\text { BMI (overweight and } \\
\text { obese) }\left(>25 \mathrm{~kg} / \mathrm{m}^{2}\right)\end{array}$ & $229(95.8)$ & $39(95.1)$ & $30(93.8)$ & 0.484 \\
\hline $\begin{array}{l}\text { Hypertension }(\geq 140 \\
\mathrm{mmHg} / 90 \mathrm{mmHg})\end{array}$ & $80(33.5)$ & $16(39)$ & $13(40.6)$ & 0.524 \\
\hline
\end{tabular}

\section{Discussion}

The low uptake of the door to door home-based screening prevented us from capturing a random sample. We suspect that the high violence and crime rates, including property-related crime, in Cape Town was a major contributing factor in the poor uptake of home-based screening [34]. The self-selection method proved to be more practicable, with over 1000 participants arriving to be screened at community-based venues over eight months (August 2017-March 2018). Accordingly, learnings from the original US diabetes prevention program advocated the usefulness of using a range of recruitment strategies and that the most successful methods may differ depending on variables, such as age, gender, and race/ethnicity [35].

Of those who were identified as at risk of developing diabetes, close to $90 \%$ (316 out of 354) presented themselves for confirmatory biochemical testing at our research clinic.

Females made up the majority $(80 \%)$ of the participants. This could be indicative of the differences in health-seeking behaviors within gender, which has been noted in the literature. However, health-seeking behaviors are complex, and gender is only one of the many contributors; other factors that have been highlighted are age, education, and socio-economic status [36,37]. In South Africa, specifically, people in urban areas have rated T2DM as having a larger impact on livelihood than those in rural areas [37]. Moreover, in South Africa, females do experience a higher burden of diabetes than their male counterparts $(11.8 \%$ vs. $7.7 \%$ ) [38]. Females also experience higher overweight $(62.2 \%$ vs. $41 \%)$, obesity ( $36 \%$ vs. $14.6 \%$ ), and physical inactivity ( $53.1 \%$ vs. $40.5 \%$ ) rates compared to males, putting females at greater risk for non-communicable diseases overall [38].

Among the participants who presented at the clinic, $67.9 \%$ had elevated HbA1c levels, including $13 \%$ with dysglycemia, classifying them as prediabetic, and $10 \%$ with newly diagnosed diabetes. This equated to close to $70 \%$ of the sample identified by the ADRS as high-risk as having prediabetes or undiagnosed T2DM.

This highlights the need for community-based risk screening, followed by confirmatory blood tests for those identified at risk. The early identification of screen-detected diabetes, followed by optimal care, may prevent or delay debilitating diabetes-related morbidity and mortality $[39,40]$. Identifying people with prediabetes creates an opportunity for prevention or, at the very least, to delay the onset of T2DM through lifestyle interventions [8,9].

Furthermore, the high cardiovascular disease (CVD) risk factor (i.e., obesity, dyslipidemia, and hypertension) burden among participants identified with high-risk on ADRS but with normoglycemia on biochemical analysis support the view that once ranked as high-risk for diabetes, people will 
benefit from lifestyle interventions, either for diabetes risk or for general CVD risk reduction. Indeed, Sattar (2013) [41] concluded that glucose-based measures might not improve CVD risk prediction in those without diabetes. Therefore, diabetes risk screening/reduction cannot be considered in isolation from the overall CVD risk screening/reduction strategy.

As part of the SA-DPP lifestyle intervention, we developed culturally and socio-economically appropriate intervention material that addressed the barriers to optimal nutrition and physical activity to promote healthy lifestyle behaviors in South African communities using evidence-based and participatory approaches [25]. This lifestyle intervention, largely based on evidence from previous and ongoing diabetes prevention programs [8-10], hopes to reduce the T2DM and CVD risk of those identified at definitive future risk for T2DM.

A systematic review and meta-analysis have found that lifestyle interventions result in significant improvements in CVD risk (such as systolic BP, diastolic BP, TC, LDL-C, HDL-C, and TG), irrespective of glycemic or diabetes status [42].

\section{Strengths and Limitations}

A strength of this study was that it was adaptive in nature and that early learnings inherently led to the successful recruitment of study participants without compromising the scope of our research. This learning in community screening efforts is key for future research efforts and others doing research in South Africa, the greater Africa, and other low-income countries. A limitation of this study was that the sample was small (pilot phase of the SA-DPP) and restricted to the Cape Town Metro (inherently different from other Metros) in the Western Cape of South Africa, and as such findings on CVD risk should be interpreted with caution.

\section{Conclusions}

Evidence has established the benefits of early detection of unknown diabetes and prediabetes for the individual (quality of life), as well as the burden (cost) on the health system [1]. Community-based screening efforts in low-resourced settings, such as South Africa, seems to be a feasible method for early detection, as corroborated by our pilot phase findings. Cost-effectiveness needs to be determined in this setting, but effectiveness has been established [6].

Author Contributions: J.H. and A.P.K. conceptualized the study. D.J. was involved in screening data collection and collected all the biological data. J.H. analyzed and interpreted data. J.H. drafted the manuscript. A.P.K., N.P., D.J., M.M., and E.S. contributed to the editing and revision of the manuscript. All authors have read and agreed to the published version of the manuscript.

Funding: This research received no external funding.

Acknowledgments: The authors would like to acknowledge the entire South African diabetes prevention program team and collaborators for their hard work and continued support, especially Erica April, the project administrator, and Samuel Sipango, the project driver.

Conflicts of Interest: The authors declare no conflict of interest.

\section{References}

1. International Diabetes Foundation (IDF). IDF Diabetes Atlas: Ninth Edition International Diabetes Federation 2019. International Diabetes Foundation (IDF): Brussels, Belgium, 2019. Available online: https://www. diabetesatlas.org/upload/resources/2019/IDF_Atlas_9th_Edition_2019.pdf (accessed on 26 March 2020).

2. International Diabetes Foundation (IDF). IDF Diabetes Atlas Eighth Edition. International Diabetes Foundation (IDF): Brussels, Belgium. Available online: https://www.idf.org/e-library/epidemiology-research/ diabetes-atlas/134-idf-diabetes-atlas-8th-edition.html (accessed on 14 April 2020).

3. Peer, N.; Steyn, K.; Lombard, C.; Lambert, E.V.; Vythilingum, B.; Levitt, N.S. Rising Diabetes Prevalence among Urban-Dwelling Black South Africans. PLoS ONE 2012, 7, e43336. [CrossRef] [PubMed] 
4. $\quad$ Erasmus, R.T.; Soita, D.J.; Hassan, M.S.; Blanco-Blanco, E.; Vergotine, Z.; Kengne, A.P.; Matsha, T.E. High prevalence of diabetes mellitus and metabolic syndrome in a South African coloured population: Baseline data of a study in Bellville, Cape Town. S. Afr. Med. J. 2012, 102, 841-844. [CrossRef] [PubMed]

5. Galaviz, K.I.; Narayan, K.M.V.; Lobelo, F.; Weber, M.B. Lifestyle and the Prevention of Type 2 Diabetes: A Status Report. Am. J. Lifestyle Med. 2015, 12, 4-20. [CrossRef] [PubMed]

6. Alouki, K.; Delisle, H.; Bermúdez-Tamayo, C.; Johri, M. Lifestyle Interventions to Prevent Type 2 Diabetes: A Systematic Review of Economic Evaluation Studies. J. Diabetes Res 2016. [CrossRef] [PubMed]

7. Lindstrom, J.; Louheranta, A.; Mannelin, M.; Rastas, M.; Salminen, V.; Eriksson, J.; Uusitupa, M.; Tuomilehto, J. The Finnish Diabetes Prevention Study (DPS): Lifestyle intervention and 3-year results on diet and physical activity. Diabetes Care 2003. [CrossRef]

8. Absetz, P.; Valve, R.; Oldenburg, B.; Heinonen, H.; Nissinen, A.; Fogelholm, M.; Ilvesmäki, V.; Talja, M.; Uutela, A. Type 2 diabetes prevention in the "real world": One-year results of the GOAL Implementation Trial. Diabetes Care 2007. [CrossRef]

9. Knowler, W.C.; Barrett-Connor, E.; Fowler, S.E.; Hamman, R.F.; Lachin, J.M.; Walker, E.A.; Nathan, D.M.; Diabetes Prevention Program Study Group. Reduction in the incidence of type 2 diabetes with lifestyle intervention or metformin. N. Engl. J. Med. 2002. [CrossRef]

10. Thankappan, K.R.; Sathish, T.; Tapp, R.J.; Shaw, J.E.; Lotfaliany, M.; Wolfe, R.; Absetz, P.; Mathews, E.; Aziz, Z.; Williams, E.D.; et al. A peer-support lifestyle intervention for preventing type 2 diabetes in India: A cluster-randomized controlled trial of the Kerala Diabetes Prevention Program. PLoS Med. 2018. [CrossRef]

11. Matsha, T.; Soita, D.J.; Hassan, M.S.; Hon, G.M.; Yako, Y.Y.; Kengne, A.P.; Erasmus, R.T. Three-year's changes in glucose tolerance status in the Bellville South cohort: Rates and phenotypes associated with progression. Diabetes Res. Clin. Pract. 2012. [CrossRef]

12. Gillies, C.L.; Abrams, K.R.; Lambert, P.C.; Cooper, N.J.; Sutton, A.J.; Hsu, R.T.; Kunti, K. Pharmacological and lifestyle interventions to prevent or delay type 2 diabetes in people with impaired glucose tolerance: Systematic review and meta-analysis. BMJ 2007. [CrossRef]

13. Parker, D.R.; Evangelou, E.; Eaton, C.B. Intraclass correlation coefficients for cluster randomized trials in primary care: The cholesterol education and research trial (CEART). Contemp. Clin. Trials 2005, 26, 260-270. [CrossRef]

14. Brown, N.; Critchley, J.; Bogowicz, P.; Mayige, M.; Unwin, N. Risk scores based on self-reported or available clinical data to detect undiagnosed Type 2 Diabetes: A systematic review. Diabetes Res. Clin. Pract. 2012. [CrossRef] [PubMed]

15. Census 2011. Available online: https://census2011.adrianfrith.com/ (accessed on 16 April 2020).

16. Wazimap. Available online: https://wazimap.co.za/ (accessed on 16 April 2020).

17. Statistics South Africa. Available online: http://www.statssa.gov.za/ (accessed on 16 April 2020).

18. Google Maps. Available online: https://www.google.co.za/maps (accessed on 16 April 2020).

19. Mayige, M. Derivation and Validation of a Simple Risk Score for Undiagnosed Diabetes for Tanzania and Other African Populations. Ph.D. Thesis, Newcastle University, Newcastle, UK, 2014.

20. Alberti, K.G.; Zimmet, P.; Shaw, J. Metabolic syndrome-A new world-wide definition. A Consensus Statement from the International Diabetes Federation. Diabetes Med. 2006. [CrossRef] [PubMed]

21. World Health Organization. Definition, Diagnosis and Classification of Diabetes Mellitus and Its Complications: Report of a WHO Consultation; World Health Organization: Geneva, Switzerland, 1999.

22. World Health Organization. Global Physical Activity Questionnaire (GPAQ); World Health Organization: Geneva, Switzerland, 2018.

23. Oyeyemi, A.L.; Kasoma, S.S.; Onywera, V.O.; Assah, F.; Adedoyin, R.A.; Conway, T.L.; Moss, S.J.; Ocansey, R.; Kolbe-Alexander, T.L.; Akinroye, K.K.; et al. NEWS for Africa: Adaptation and reliability of a built environment questionnaire for physical activity in seven African countries. Int. J. Behav. Nutr. Phys. Act. 2016. [CrossRef]

24. The Jackson Heart Study. Jackson Heart Medical Form [Cited 2020]. Available online: https://www. jacksonheartstudy.org/ (accessed on 14 April 2020).

25. Hill, J.; Lavigne Delville, C.; Auorousseau, A.-M.; Jonathan, D.; Peer, N.; Oldenburg, B.; Kengne, A.P. Development of a Tool to Increase Physical Activity among People at Risk for Diabetes in Low-Resourced Communities in Cape Town. Int. J. Environ. Res. Public Health 2020, 17, 865. [CrossRef] [PubMed] 
26. Booth, M.L.; Bauman, A.; Owen, N.; Gore, C.J. Physical activity preferences, preferred sources of assistance, and perceived barriers to increased activity among physically inactive Australians. Prev. Med. 1997. [CrossRef] [PubMed]

27. Labadarios, D.; Steyn, N.P.; Nel, J. How diverse is the diet of adult South Africans? Nutr. J. 2011, 10, 33. [CrossRef]

28. Schwarzer, R.; Jerusalem, M. Generalized Self-Efficacy scale. In Measures in Health Psychology: A User's Portfolio. Causal and Control Beliefs; Weinman, J., Wright, S., Johnston, M., Eds.; NFER-NELSON: Windsor, UK, 1995; pp. 35-37.

29. Bromberger, J.T.; Matthews, K.A. A longitudinal study of the effects of pessimism, trait anxiety, and life stress on depressive symptoms in middle-aged women. Psychol. Aging 1996, 11, 207-213. [CrossRef]

30. Poongothai, S.; Pradeepa, R.; Ganesan, A.; Mohan, V. Reliability and validity of a modified PHQ-9 item inventory (PHQ-12) as a screening instrument for assessing depression in Asian Indians (CURES-65). J. Assoc. Physicians India 2009, 57, 147-152.

31. Spitzer, R.L.; Kroenke, K.; Williams, J.B.; Lowe, B. A brief measure for assessing generalized anxiety disorder: The GAD-7. Arch. Intern. Med. 2006, 166, 1092-1097. [CrossRef]

32. Mitchell, P.H.; Powell, L.; Blumenthal, J.; Norten, J.; Ironson, G.; Pitula, C.R.; Froelicher, E.S.; Czajkowski, S.; Youngblood, M.; Huber, M.; et al. A short social support measure for patients recovering from myocardial infarction: The ENRICHD Social Support Inventory. J. Cardiopulm. Rehabil. 2003, 23, 398-403. [CrossRef]

33. Ware, J.E., Jr.; Sherbourne, C.D. The MOS 36-item short-form health survey (SF-36). I. Conceptual framework and item selection. Med. Care 1992, 30, 473-483. [CrossRef] [PubMed]

34. Poswa, N. All Reported Crime trends in Cape Town 2005/6-2016/17 and Crime Rates by Police Precincts in Cape Town 2011/12, 2014/15, 2015/16 and 2016/17. Factsheet, Data and Maps Extracted; Organisational Policy and Planning Department, City of Cape Town: Cape Town, South Africa, 2018.

35. Rubin, R.R.; Fujimoto, W.Y.; Marrero, D.G.; Brenneman, T.; Charleston, J.B.; Edelstein, S.L.; Fisher, E.B.; Jordan, R.; Knowler, W.C.; Lichterman, L.C.; et al. The Diabetes Prevention Program: Recruitment methods and results. Control Clin. Trials 2002, 23, 157-171. [PubMed]

36. Thompson, A.E.; Anisimowicz, Y.; Miedema, B.; Hogg, W.; Wodchis, W.P.; Aubrey-Bassler, K. The influence of gender and other patient characteristics on health care-seeking behaviour: A QUALICOPC study. BMC Fam. Pract. 2016, 17, 38. [CrossRef] [PubMed]

37. Van der Hoeven, M.; Kruger, A.; Greeff, M. Differences in health care seeking behaviour between rural and urban communities in South Africa. Int. J. Equity Health 2012, 11, 31. [CrossRef]

38. World Health Organization. Diabetes Country Profiles: South Africa; World Health Organization: Geneva, Switzerland, 2016.

39. Herman, W.H.; Ye, W.; Griffin, S.J.; Simmons, R.K.; Davies, M.J.; Khunti, K.; Rutten, G.E.H.M.; Sandbaek, A.; Lauritzen, T.; Borch-Johnsen, K.; et al. Early Detection and Treatment of Type 2 Diabetes Reduce Cardiovascular Morbidity and Mortality: A Simulation of the Results of the Anglo-Danish-Dutch Study of Intensive Treatment in People With Screen-Detected Diabetes in Primary Care (ADDITION-Europe). Diabetes Care 2015, 38, 1449. [CrossRef]

40. Marshall, S.M.; Flyvbjerg, A. Prevention and early detection of vascular complications of diabetes. BMJ 2006, 333, 475-480. [CrossRef]

41. Sattar, N. Revisiting the links between glycaemia, diabetes and cardiovascular disease. Diabetologia 2013, 56, 686-695. [CrossRef]

42. Zhang, X.; Devlin, H.M.; Smith, B.; Imperatore, G.; Thomas, W.; Lobelo, F.; Ali, M.K.; Norris, K.; Gruss, S.; Bardenheier, B.; et al. Effect of lifestyle interventions on cardiovascular risk factors among adults without impaired glucose tolerance or diabetes: A systematic review and meta-analysis. PLoS ONE 2017, 12, e0176436. [CrossRef]

(C) 2020 by the authors. Licensee MDPI, Basel, Switzerland. This article is an open access article distributed under the terms and conditions of the Creative Commons Attribution (CC BY) license (http://creativecommons.org/licenses/by/4.0/). 